\title{
Efficacy of entomopathogenic nematodes for control of large pine weevil, Hylobius abietis: effects of soil type, pest density and spatial distribution
}

\author{
Apostolos Kapranas ${ }^{1,6}$ (D) Ben Malone ${ }^{1} \cdot$ Sarajane Quinn $^{1} \cdot$ Louise Mc Namara $^{2}$. \\ Christopher D. Williams ${ }^{3} \cdot$ Padraig O'Tuama $^{4} \cdot$ Arne Peters $^{5} \cdot$ Christine T. Griffin $^{1}$
}

Received: 4 November 2016/Revised: 24 November 2016/Accepted: 29 November 2016/Published online: 8 December 2016

(C) Springer-Verlag Berlin Heidelberg 2016

\begin{abstract}
The large pine weevil Hylobius abietis (L.), LPW, is a major pest of trees in replanted coniferous forests in northern Europe. The use of entomopathogenic nematodes (EPNs) applied against developing stages for population suppression is increasingly recognized as an effective alternative to plant protection using chemical pesticides. Here, we report results from a series of trials we conducted over 2 years using two species of EPN, Steinernema carpocapsae (Weiser) and Heterorhabitis downesi (Stock, Griffin, and Burnell) with different foraging strategies. Trials were conducted at lodgepole pine sites in Ireland on both mineral and peat soil type. EPN suspension was applied to the stumps of felled pine trees, and EPN efficacy was determined afterwards by directly assessing
\end{abstract}

Communicated by A. Battisti.

Electronic supplementary material The online version of this article (doi:10.1007/s10340-016-0823-y) contains supplementary material, which is available to authorized users.

Apostolos Kapranas

apostolos.kapranas@unine.ch

1 Department of Biology, Maynooth University, Maynooth, Co. Kildare, Ireland

2 Teagasc, Oak Park Research Centre, Co. Carlow, Ireland

3 School of Natural Sciences and Psychology, Liverpool John Moores University, Liverpool L3 3AF, UK

4 Coillte Forest, Hartnetts Cross, Macroom, Co. Cork, Ireland

5 E-nema GmbH, Klausdorfer Str. 28-36, 24223 Schwentinental, Germany

6 Present Address: Institute of Biology, University of Neuchâtel, 2000 Neuchâtel, Switzerland parasitism rates after debarking one quarter of the stumps and by collecting emerging adult weevils from traps erected over other treated and control stumps. Our results suggest that both species of EPN are equally effective in suppressing LPW populations to below the current, informal thresholds of economic damage. EPN were equally efficient in controlling LPW in peat and in mineral (lithosols/regosols and acid brown earth/brown podzolics) soils. Weevil density and distribution within pine stumps in peat versus mineral sites can explain patterns of LPW parasitism and suppression. Our results also suggest that infestation level (number of weevils per stump) can be an important factor in forecasting EPN application success as there is evidence of negative density-dependent parasitism when weevil densities were high.

Keywords Forest pest - Root-feeding insect . Entomopathogenic nematodes - Foraging strategy ·

Soil type $\cdot$ Density-dependent parasitism

\section{Key message}

- Entomopathogenic nematodes (EPNs) were applied to conifer stumps for control of the large pine weevil Hylobius abietis LPW.

- Species with different foraging strategies (ambushers vs cruisers) provided the same level of control.

- EPN efficacy is predicted to be increased in organic soils. However, EPN efficacy in suppressing LPW populations in peaty (organic rich) and in mineral soils was equal.

- Weevil density and spatial distribution within stumps, which both vary depending on soil type, explain patterns of EPN parasitism and pest suppression. 


\section{Introduction}

The large pine weevil Hylobius abietis (L.) (Coleoptera: Curculionidae) is the most important pest of tree seedlings in replanted coniferous forests in northern Europe, costing an estimated $€ 140$ million in Europe of which $€ 2.75$ million in the UK alone (Evans et al. 2015). The weevils are attracted to clear-felled areas by volatile chemicals emitted by the stumps of recently felled trees; they oviposit in the stumps and immature weevils develop under the bark of stumps and roots where development can take 12-36 months (Leather et al. 1999). Upon emergence, in late summer to autumn of the year following oviposition (for pines in Ireland), adult weevils feed on young seedlings and can destroy $100 \%$ of newly planted trees with an estimated mortality in UK and Ireland of 50\% within the first few years in sites not treated with insecticides (Heritage and Moore 2001). A single adult can damage or kill several young plants (Eidmann and Lindelöw 1997; Wainhouse et al. 2007), and thus, even a low number of adults emerging from stumps can have a significant impact on sites that have been replanted. In recent years, concerns over weevil damage have increased due to climate change and rising temperatures which not only leads to a shorter life cycle and increased flight and dispersal of the LPW (Tan et al. 2010; Inward et al. 2012), but also shifts in the distribution of areas suitable for LPW (Barredo et al. 2015).

Current practices for managing LPW rely on a variety of chemical, cultural and biological methods. Treatment of the young plants prior to planting with pyrethroids and an additional top-up spray of planted trees is the most popular method, but cypermethrin and alpha-cypermethrin, the most effective pesticides, are only available for use in UK and Ireland for a limited period under derogation from the Forest Stewardship Council (Anonymous 2014). In addition, concerns over environmental impacts lead to withdrawal of many synthetic pesticides based on EU directives (EC 1991, 2009a). Before pesticides are used, biological control measures, together with physical and other nonchemical methods, should have first preference (EC 2009b). Delay of restocking sites for at least 2 years has been reported to be helpful if there are no clear-felled areas nearby (Leather et al. 1999; Örlander and Nilsson 1999; Örlander and Nordlander 2003). Management of felling and restocking dates using decision support systems integrated with GIS to minimize weevil impacts has become standard practice in the UK (Evans et al. 2004; Wainhouse et al. 2007). Entomopathogenic nematodes (EPNs) applied in an inundative fashion are a promising tool in the management of the pine weevil (Torr et al. 2005; Brixey et al. 2006; Dillon et al. 2006, 2007, 2008; Williams et al. 2013a). In addition, they are environmentally safe (Ehlers and Hokkanen 1996) and have little impact on non-target species in the pine weevil habitat (Dillon et al. 2012).

Previous trials in Ireland have shown that the most promising species is the native Heterorhabditis downesi, a cruise-foraging nematode (Dillon et al. 2006; Williams et al. 2013a). However, these studies also highlighted that Steinernema carpocapsae (Weiser), an ambush-type forager, can also be quite effective against LPW, contrary to the assumption that EPNs with an ambush foraging strategy are not efficient in controlling subterranean pests (Gaugler et al. 1997; Grewal et al. 2005). The former species occurs naturally in Ireland, Britain and in continental Europe (Stock et al. 2002), but it is still not commercially produced, whereas the latter is cultured by many commercial producers of biological control agents, and thus, it is readily available for use in management of LPW. Furthermore, a meta-analysis study has shown that the efficacy of EPN against LPW is predicted to be greater in peat soils which are characterized by a high level of organic matter than in mineral soils which have lower organic matter (Williams et al. 2013b).

As part of the BIOCOMES (2013-2017) consortium which promotes the development and use of biopesticides, our purpose in these studies was to directly compare the two species $H$. downesi and $S$. carpocapsae which seem to show the most promising results against LPW. In contrast to previous trials (Dillon et al. 2006; Williams et al. 2013b), where $H$. downesi was produced in wax moth larvae, in the present study both nematode species were produced in bioreactors under commercial conditions (Ehlers and Shapiro-Ilan 2005). Moreover, we explicitly tested the conclusion of the meta-analysis that peat soils favour nematode control of LPW by including both peaty and mineral soils in each of two trial years. We conducted all our trials in pine sites (Pinus spp.), as weevils develop in higher numbers than in spruce (Picea spp.) (von Sydow and Birgersson 1997; Thorpe and Day 2002; Williams et al. 2013b). A direct relationship between number of weevils developing in stumps and subsequent damage by adults on replanted seedlings has not yet been demonstrated; however, current experience and practice in both Ireland and the UK (Wainhouse et al. 2007; unpublished note Coillte, Ireland) show that 20 weevils/stump will result in emergence of adult weevils at levels requiring plant protection. Previous studies have compared nematode efficacy in relation to control stumps, but in this set of trials we also directly compare numbers of adult weevils emerging from stumps with the target threshold which should be more informative for foresters and pest management decisionmakers. Lastly we investigate how weevil infestation and 
spatial distribution within stumps influence EPN parasitism and consequently efficacy in controlling LPW.

\section{Materials and methods}

\section{Sites of field studies}

Trials were conducted on three field sites in 2014 and on four field sites in 2015 which are summarized in Table 1. All sites were clear-felled lodgepole pine Pinus contorta Dougl. var. latifolia. Sites were categorized as peat and as mineral (ca. $5-10 \mathrm{~cm}$ of organic litter layer overlying mineral soil). Mineral soils were further classified to the respective great soil group by reference to the interactive soil maps of the National Biodiversity Data Centre (http:// maps.biodiversityireland.ie/), but due to the small number of each type this categorization was not taken into account in the analyses. At each site, treatments were arranged in a randomized block design with each block bearing a control stump, a stump treated with $S$. carpocapsae and a stump treated with $H$. downesi. On each site, there were 20 blocks; 10 of these blocks were reserved for assessment of parasitism rates (destructive sampling of 30 stumps) and the other 10 were used for monitoring emergence of weevils (placement of traps over 30 stumps). Stumps were approximately of equal size across all treatments and sites. Application of nematodes took place at the time that weevils were in late larval and/or pupal stage, which was confirmed by destructively sampling a number of stumps one to 2 weeks before the application.

\section{Application of entomopathogenic nematodes}

S. carpocapsae (EN03) and H. downesi (K122) used for the trials were provided by e-nema GmbH. Packages with EPN infective juveniles (IJs) were stored for less than a week at $9{ }^{\circ} \mathrm{C}$ until the day of application. On the day of application, aqueous suspensions were prepared and kept in 5-L bottles with aquarium pumps for aeration until they were transferred to the field. At the field, $500 \mathrm{ml}$ of the suspension $\left(\sim 3.5 \times 10^{6} \mathrm{IJs}\right)$ was applied around the base of each stump (Torr et al. 2005). In control stumps, there was no treatment (application of only water as control does not have any effect based on earlier studies).

\section{Assessment of efficacy}

Efficacy of treatments was assessed by destructive sampling (hacking) 4 weeks after application of EPNs and by trapping adult weevils emerging from stumps, following established methods (e.g. Dillon et al. 2006, 2007, 2008). Destructive sampling was performed by removing the bark of about one quarter of the stump with a chisel to a depth of at least $40 \mathrm{~cm}$ under the soil surface by clearing away the soil from the stump and associated roots, and recording the stage (larva, pupa, adult), status (healthy, parasitized by nematode, parasitized by fungi, dead by undetermined reason) and location (depth relative to soil level and
Table 1 Location and characteristics of field sites

\begin{tabular}{|c|c|c|c|c|c|}
\hline Site name & Location & Altitude & Soil type & Felling month/year & Application date \\
\hline Cloondara & $\begin{array}{l}\text { Co. Longford } \\
53^{\circ} 44^{\prime} 16.7^{\prime \prime} \mathrm{N} 7^{\circ} 54^{\prime} 15.7^{\prime \prime} \mathrm{W}\end{array}$ & $41 \mathrm{~m}$ & Peat $^{\mathrm{a}}$ & $04-05 / 2013$ & 12 June 2014 \\
\hline Knockaville & $\begin{array}{l}\text { Co. Westmeath } \\
53^{\circ} 29^{\prime} 25.9^{\prime \prime} \mathrm{N} 7^{\circ} 13^{\prime} 46.0^{\prime \prime} \mathrm{W}\end{array}$ & $95 \mathrm{~m}$ & Peat $^{b}$ & $07-08 / 2013$ & 10 June 2014 \\
\hline Killurney & $\begin{array}{l}\text { Co. Tipperary } \\
52^{\circ} 25^{\prime} 01.5^{\prime \prime} \mathrm{N} 7^{\circ} 36^{\prime} 13.0^{\prime \prime} \mathrm{W}\end{array}$ & $371 \mathrm{~m}$ & Mineral $^{\mathrm{c}}$ & 03-04/2013 & 13 June 2014 \\
\hline Clonoghil & $\begin{array}{l}\text { Co. Laois } \\
52^{\circ} 58^{\prime} 45.8^{\prime \prime} \mathrm{N} 7^{\circ} 37^{\prime} 35.5^{\prime \prime} \mathrm{W}\end{array}$ & $127 \mathrm{~m}$ & Peat $^{b}$ & $04-06 / 2014$ & 27 May 2015 \\
\hline Doon & $\begin{array}{l}\text { Co. Offaly } \\
53^{\circ} 19^{\prime} 53.6^{\prime \prime} \mathrm{N} 7^{\circ} 51^{\prime} 42.3^{\prime \prime} \mathrm{W}\end{array}$ & $57 \mathrm{~m}$ & Peat $^{b}$ & 03-03/2014 & 03 June 2015 \\
\hline Tigroney & $\begin{array}{l}\text { Co. Wicklow } \\
52^{\circ} 53^{\prime} 04.5^{\prime \prime} \mathrm{N} 6^{\circ} 12^{\prime} 11.6^{\prime \prime} \mathrm{W}\end{array}$ & $207 \mathrm{~m}$ & Mineral $^{\mathrm{c}}$ & 06-08/2013 & 17 June 2015 \\
\hline Gurtnapisha & $\begin{array}{l}\text { Co. Tipperary } \\
52^{\circ} 26^{\prime} 33.3^{\prime \prime} \mathrm{N} 7^{\circ} 33^{\prime} 32.9^{\prime \prime} \mathrm{W}\end{array}$ & $466 \mathrm{~m}$ & Mineral $^{\mathrm{d}}$ & $01-02 / 2014$ & 09 June 2015 \\
\hline
\end{tabular}

\footnotetext{
${ }^{a}$ Fen peat

b Raised bog/cutaway

c Lithosol/regosol

d Acid brown earths/brown podzols
} 
distance from bole) of each individual pine weevil. Weevils that are parasitized by nematodes have a characteristic colour and texture; a proportion of weevils were also dissected to confirm the accuracy of the status designation. Weevils were removed with clean forceps, placed in 24-well plates and transferred to the laboratory. They were then incubated at $\sim 20{ }^{\circ} \mathrm{C}$ for another 2 weeks to check for post-sampling EPN mortality.

Emergence traps based on Moore (2001), but without the electric shock mechanism, were erected about 2 weeks after EPN application and were then sampled every 2-4 weeks throughout the season, starting mid-July until weevil emergence ceased in November. For the control stumps, we also compared directly the weevil number (all stages) observed during hacking (multiplied by four) with the ones collected in the traps. However, a limited number of control stumps (see Table 2) were hacked in 2015 due to the limited time window to complete the volume of work.

\section{Statistical analysis}

Comparison of 'in-root' weevil distribution-depth under soil surface and distance from bole-between mineral and deep peat sites was achieved with a nonparametric Kolmogorov-Smirnov test. Standard $t$ tests were used to compare the number of adult weevils caught in traps with the number of developing weevils found during hacking (both variables for control stumps only) in order to assess weevil emergence and also to compare in-root depth and distance of weevils between peat and mineral sites. Analysis of factors influencing immature weevil parasitism rates and adult weevil emergence was performed with generalized linear models (GLMs) (Crawley 1997). We assumed quasi-binomial error variance for parasitism (proportional) data, and significance of effects was assessed by the change in deviance when a variable was removed from the full model. We also used a mixed effect logistic regression analysis to explore parasitism rates in relation to depth below soil surface and horizontal distance from the bole of the stump. Nematode species (two-level factor), weevil number, site, depth and distance were introduced as fixed effects, whereas each stump was introduced in the analysis as a random effect. We present the raw means of proportional data because they are biologically more relevant than transformed data along with asymmetrical standard errors. All analyses were performed using GENSTAT statistical package (Version 14, VSN International, Hemel Hempstead, UK).

For emergence data (cumulative trap collections over the season) which followed a normal distribution based on Anderson-Darling test, we used a two-way ANOVA with nematode species and site introduced as factors; the controls from this analysis were excluded as the purpose was to compare the two EPN species at different locations. Analysis was performed separately for each year. In addition, we performed one-way ANOVAs followed by a

Table 2 Population structure and abundance of Hylobius abietis in control stumps 4 weeks post-application and comparison with number of weevils caught in emergence traps over the remainder of the season

\begin{tabular}{|c|c|c|c|c|c|c|c|c|}
\hline $\begin{array}{l}\text { Site name (no. } \\
\text { stumps) }\end{array}$ & $\begin{array}{l}\text { Larvae } \\
(\%)\end{array}$ & $\begin{array}{l}\text { Pupae } \\
(\%)\end{array}$ & $\begin{array}{l}\text { Adults } \\
(\%)\end{array}$ & Totals & $\begin{array}{l}\text { Weevils within } \\
20 \mathrm{~cm} \text { depth }(\%)\end{array}$ & $\begin{array}{l}\text { Weevils within } 50 \mathrm{~cm} \\
\text { distance from bole }(\%)\end{array}$ & $\begin{array}{l}\text { Hacking } \\
\text { average } \pm \mathrm{SE}^{\mathrm{a}}\end{array}$ & $\begin{array}{l}\text { Difference from } \\
\text { emergence }^{b}\end{array}$ \\
\hline Cloondara (10) & 38.02 & 33.33 & 28.64 & 192 & 77.73 & 97.8 & $76.8 \pm 11.2$ & $\begin{array}{l}t=0.74 \\
P=0.465\end{array}$ \\
\hline Knockaville (10) & 53.03 & 33.03 & 13.95 & 215 & 71.06 & 96.5 & $86.0 \pm 22.9$ & $\begin{array}{l}t=1.33 \\
P=0.19\end{array}$ \\
\hline Killurney (10) & 18.18 & 68.18 & 13.63 & 132 & 90.9 & 98.3 & $52.8 \pm 9.4$ & $\begin{array}{l}t=3.50 \\
P<0.05\end{array}$ \\
\hline Clonoghil (8) & 89.47 & 10.53 & 0.00 & 304 & 45.02 & 71.8 & $152 \pm 26.9$ & $\begin{array}{l}\mathrm{t}=0.30 \\
\mathrm{P}=0.076\end{array}$ \\
\hline Doon (6) & 50.25 & 49.25 & 0.50 & 197 & 70.28 & 75.6 & $131.3 \pm 24.9$ & $\begin{array}{l}t=3.27 \\
P<0.05\end{array}$ \\
\hline Tigroney (4) & 4.54 & 88.64 & 6.82 & 44 & 68.98 & 96.3 & $44 \pm 12.1$ & $\begin{array}{l}t=0.12 \\
P=0.902\end{array}$ \\
\hline Gurtnapisha (6) & 76.00 & 24.00 & 0.00 & 75 & 85.62 & 85.6 & $50 \pm 12.5$ & $\begin{array}{l}t=3.90 \\
P<0.05\end{array}$ \\
\hline
\end{tabular}

${ }^{\text {a }}$ Estimated per stump after multiplying by 4

${ }^{\mathrm{b}}$ Difference between number of weevils found per stump at hacking (ca. 4 weeks post-application) and number of adult weevils collected in traps erected over control stumps (compare with control graphs of Fig. 5) 
Kramer-Tukey test, to detect differences among means across all site and treatment combinations, with the controls included. Within sites, we compared different treatments with a Fisher's least significant difference (LSD) procedure which is a more liberal post hoc test, while preserving the experiment-wise type I error rate at the nominal level of significance, if the number of treatment groups is three (Meier 2006). A complementary one-tailed $t$ test comparing trap catches with a mean of 20 , which is the number of weevils per stump that are indicated as a threshold for chemical treatment as recommended by Coillte (Ireland's national forestry company), was also performed.

\section{Results}

\section{Population structure and distribution of weevils in stumps}

Based on hacking control stumps 4 weeks post-application, weevils seemed to be earlier in their development in 2015 than 2014 (Table 2). Weevil distribution in stump roots was different between peat and mineral sites (Fig. 2, Kolmogorov-Smirnov test for comparing distributions between two samples, depth relative to soil surface: $D=0.064$, $P<0.001$; distance from bole of stump: $D=0.099$, $P<0.05)$. The average depth of weevils was greater in peat versus mineral sites $(14.89 \pm 0.236 \mathrm{~cm}$ vs $\left.12.51 \pm 0.387 \mathrm{~cm} ; t_{2690}=4.904, P<0.001\right)$. Similarly, the average distance of weevils from bole was greater in peat vs mineral sites $(13.57 \pm 0.351 \mathrm{~cm} \quad$ vs $\left.11.23 \pm 0.561 \mathrm{~cm} ; \quad t_{2690}=3.264, \quad P=0.001\right)$. Thus, weevils were more likely to be found in the roots deepest and farthest from the bole in stumps on peat than in stumps on mineral soils (Fig. 1). The site in Clonoghil (peat) had a much higher percentage of weevils at depths $>20 \mathrm{~cm}$ compared to the other sites-55\% versus $9-31 \%$ for the other six sites (Table 2).

There was also a positive relationship between the number of weevils per stump and their average distance from the bole of the stump (GLM with weevils: $F_{1,115}=22.46, \quad P<0.001 ; \quad$ soil type: $F_{1,115}=3.83$, $P=0.053$ ), but there was not a significant relationship between weevil number and average depth (GLM with weevils: $\quad F_{1,115}=0.13, \quad P=0.720 ; \quad$ soil type: $\left.F_{1,115}=3.83, P=0.053\right)$.

\section{Parasitism rates: differences among sites and nematode species}

Parasitism rates (after a 2 week post-sampling incubation period) were the same for both nematode species in both years (GLM analysis, 2014: $F_{1,56}=2.18, \quad P=0.116$; 2015; $F_{1,68}=0.61, P=0.437$, Fig. 2). Parasitism rates did not differ across the three sites in $2014\left(F_{2,56}=2.27\right.$, $P=0.114$ ), but they were significantly different across sites in $2015\left(F_{3,68}=14.37, P<0.001\right)$. However, no clear trend existed in comparing parasitism rates between peat and mineral sites (Fig. 3). The interactions between site and nematode species were insignificant for both years and are not shown.

\section{Effects of pine weevil infestation on parasitism rates}

For the year 2014, we found no effects of weevil number per stump on parasitism rates $\left(F_{1,56}=0.3, P=0.584\right)$, but in 2015 parasitism rates were inversely correlated with weevil number per stump $\left(F_{1,68}=6.48, \quad P=0.014\right.$, Fig. 3). Despite a strong negative trend, the effect of number of weevils on parasitism rates was not significant when data from both years were combined $\left(F_{1,125}=3.27\right.$, $P=0.074$ ) but was significant when instead of site, soil type (peat vs mineral) was introduced in the model $\left(F_{1,125}=12.83, P<0.001\right)$.

\section{Parasitism rates in relation to root depth and distance from the stump}

Logistic analysis showed that LPW parasitism rates were significantly lower at greater depths in soil $\left(F_{1,2684}=70.85, P<0.001\right)$ and at greater distance from the bole of the stumps $\left(F_{1,2684}=239.76, P<0.001\right)$. Parasitism rates in relation to depth and distance did not differ between the two nematode species $\left(F_{1,2684}=0.13\right.$, $P=0.719)$, but they did differ significantly among sites $\left(F_{6,2684}=68.1, P<0.001\right)$. Furthermore, the interactions between site, depth and distance were also significant (site*depth: $\quad F_{6,2684}=2.54, \quad P=0.019, \quad$ site*distance: $\left.F_{6,2684}=5.00, P<0.001\right)$. However, trends of parasitism rates in relation to depth and distance among sites of different soil type (peat versus mineral) were not clear.

\section{Emergence of pine weevils}

Numbers of adult LPW emerging from stumps treated with $H$. downesi or with $S$. carpocapsae did not differ in either year (Table 3; Figs. 4, 5). Numbers of emerging adult LPW from stumps treated with both species also did not differ among the three sites in 2014, but they significantly differed among sites in 2015, due to the high infestation in the Clonoghil site (Table 2; Figs. 4, 5).

In 2014, the number of LPW emerging from stumps treated with $H$. downesi was significantly lower compared with the controls across all three sites, whereas $S$. carpocapsae was effective in two sites (both of peat) (Fig. 4). 
Fig. 1 Hylobius abietis distribution (depth from soil surface and distance from bole in $\mathrm{cm}$ ) in pine stumps
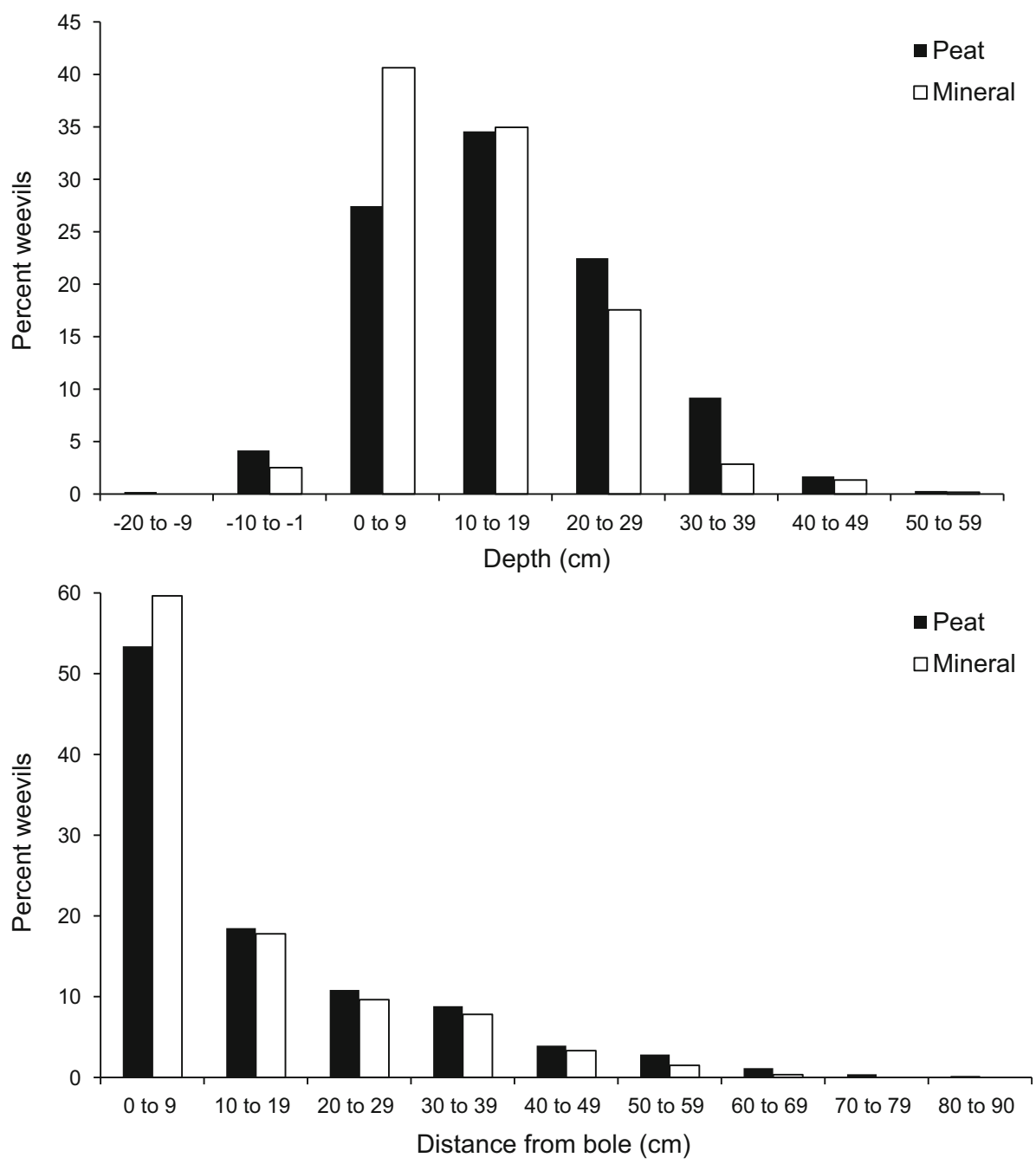

In 2015, applications of both nematode species led to significant suppression of LPW adult emergence in three out of four sites (Fig. 5). The site at which application did not lead to significant suppression was a peat site (Clonoghil).

In one site (Gurtnapisha, mineral), the average adult weevil number/control stump was lower than the suggested threshold of 20 weevils/stump and from a management perspective there was no need for treating this site (Fig. 5). However, the higher number of weevils in control stumps at destructive sampling than the number of adult weevils collected in traps indicates that weevil emergence during the late summer-autumn was incomplete (Table 2). In the remaining six sites, treatment with EPN led to suppression of weevil emergence below the suggested threshold of 20 weevils/stump in five out of six sites, but for each location one species only provided the level of control sought; however, there was no relationship between soil type and which species was most effective (Figs. 4, 5).

\section{Assessment of weevil emergence}

In three sites (one in 2014 and two in 2015), weevil emergence was determined to be incomplete based on comparisons between weevils found in stumps during hacking and adult weevils collected in traps, in control stumps. Two of these sites were mineral (Killurney 2014 and Gurtnapisha 2015, Table 2).

\section{Discussion}

Our study confirms previous studies, showing that the use of EPN can be efficient in controlling LPW (Dillon et al. 2006, 2007). However, it adds new information that is highly pertinent to controlling LPW by application of EPN and also suggests that the importance of factors such as soil type and infestation load (i.e. number of weevils developing in the stump, Williams et al. 2013b) should be at least 
Fig. 2 Percentage parasitism of Hylobius abietis by

Heterorhabditis downesi and Steinernema carpocapsae in stumps at different sites in 2014 (a) and 2015 (b). Bars show average values with asymmetrical, quasi-binomially distributed standard errors. Peat. peaty soil type, $\min$. mineral soil type
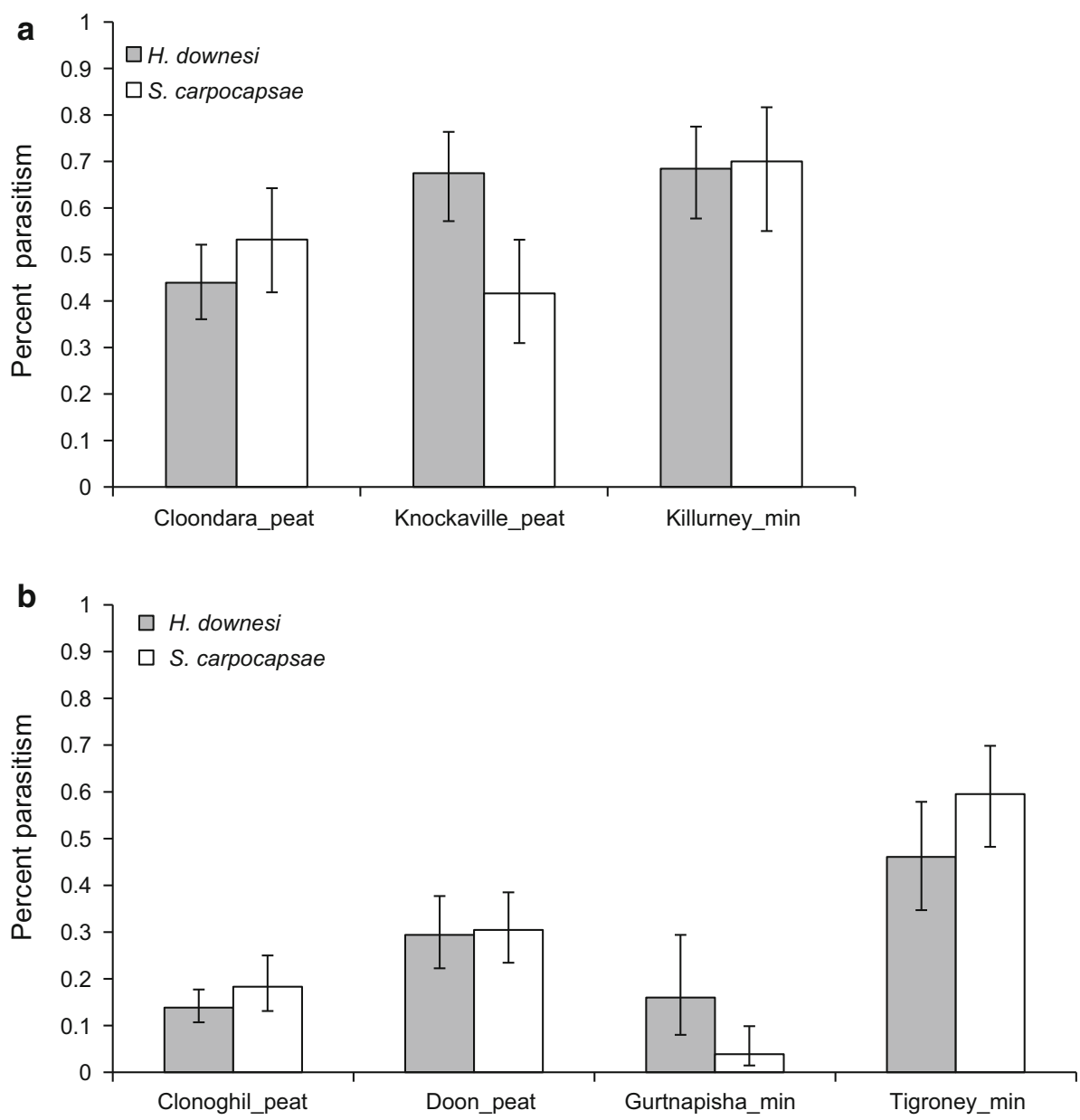

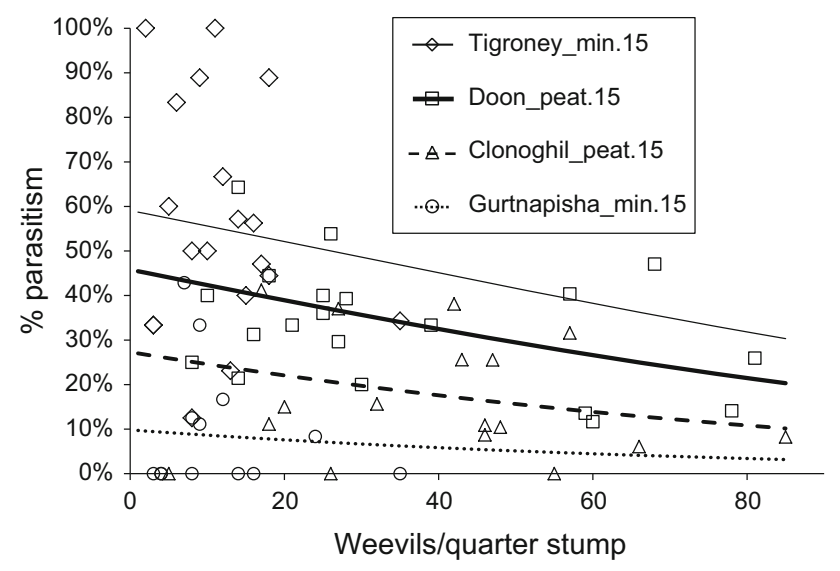

Fig. 3 Influence of Hylobius abietis infestation (number of weevils/ quarter stump) on parasitism rates by entomopathogenic nematodes across different sites on the year 2015

considered in future. Differences in parasitism rates were strikingly different among the 2 years of our trials. Ambient and soil temperatures were higher in 2014 than in 2015 especially in June and July, the months immediately following application (supplementary material). In addition
Table 3 Effect of nematode species and site on the emergence of adult Hylobius abietis

\begin{tabular}{|c|c|c|c|c|c|c|}
\hline \multirow[t]{2}{*}{ Source } & \multicolumn{3}{|c|}{2014} & \multicolumn{3}{|c|}{2015} \\
\hline & $d . f$ & $F$ & $P$ & d.f & $F$ & $P$ \\
\hline Species & 1 & 1.07 & 0.306 & 1 & 0.01 & 0.930 \\
\hline Site & 2 & 0.77 & 0.468 & 3 & 27.87 & $<0.001$ \\
\hline Species $\times$ Site & 2 & 1.37 & 0.262 & 3 & 0.25 & 0.861 \\
\hline Error & 54 & & & 72 & & \\
\hline Total & 59 & & & 79 & & \\
\hline
\end{tabular}

Control stumps are excluded

to the direct effect of temperature on nematode efficacy (Grewal et al. 1994; Wilson et al. 2016), the higher temperatures of 2014 may have influenced nematode efficacy indirectly through an effect on weevil development. In 2014, weevils were more advanced in their development at the time of application. While LPW pupae are in general less susceptible to EPN than are larvae, there is evidence that both newly pupated insects and callow adults are 
Fig. 4 Numbers of adult Hylobius abietis (average \pm SE) emerging from control stumps and stumps treated with entomopathogenic nematodes (Heterorhabditis downesi and Steinernema carpocapsae) across three sites in the year 2014. Capital letters above bars show significantly different treatments across all sites (Tukey-Kramer test), and asterisks show Fisher's (LSD) post hoc tests within each site separately. Checkmarks denote treatments wherein weevil numbers are less than 20/stump (denoted by the horizontal dashed line)

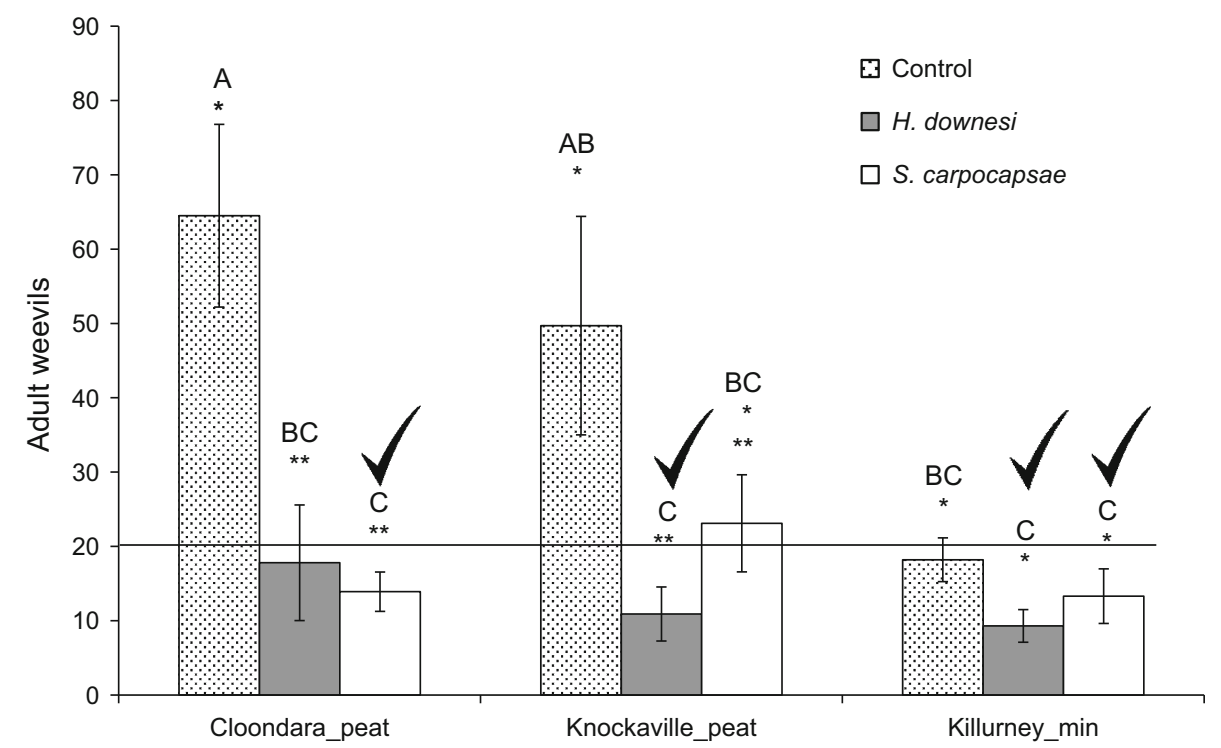

Fig. 5 Numbers of adult Hylobius abietis (average \pm SE) emerging from control stumps and stumps treated with entomopathogenic nematodes (Heterorhabditis downesi and Steinernema carpocapsae) across three sites in the year 2015. Capital letters above bars show significantly different treatments across all sites (Tukey-Kramer test), and asterisks show Fisher's (LSD) post hoc tests within each site separately. Checkmarks denote treatments wherein weevil numbers are less than 20/stump (denoted by the horizontal dashed line)

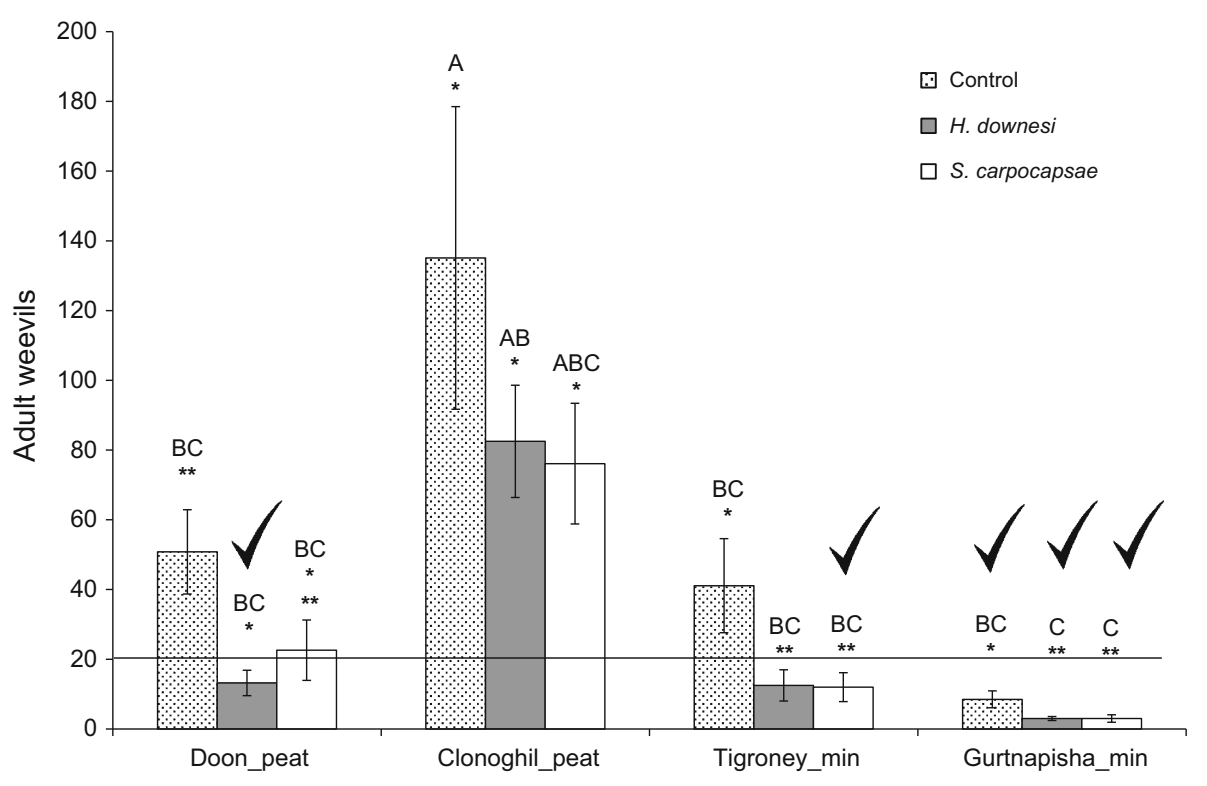

susceptible (Williams et al. 2015). Application at a time when many of weevils are transitioning from larva to pupa, or from pupa to callow adult, may favour successful parasitism by EPN.

Overall, our trials suggest that both $H$. downesi and $S$. carpocapsae are equally efficient in parasitizing the LPW developing in stumps and subsequently suppressing adult numbers coming out of the stumps. This is perhaps not surprising; although previous studies showed that $H$. downesi is superior to $S$. carpocapsae, it was suggested that the latter should not be underrated as a biological control agent (Dillon et al. 2006, 2007). In our trials, S. carpocapsae not only provided considerable suppression relative to controls in many cases, but also suppressed the numbers of emerging adult weevils below the targeted threshold of 20/stump, as many times as $H$. downesi did. It is also noteworthy that in the current study parasitism rates in relation to depth and distance from the base of the stump were equal for both species. These results are also intriguing given the ambushing foraging behaviour of this species; because S. carpocapsae can find and infect relatively immobile insects at considerable distances even deep within soil, the current classification of EPN based on their foraging behaviour (ambushers vs cruisers) is under question (Wilson et al. 2012; Griffin 2015). On the other hand, it might be possible that nematodes are carried passively along the roots either by the suspension water or later through rainfall which was adequate in summer of both years (supplementary material). Other studies have similarly confirmed the effectiveness of $S$. carpocapsae in 
parasitizing and controlling other root-feeding insects (Jansson et al. 1993; de Altube et al. 2008). The H. downesi used in the present experiments was the same strain as used in our previous trials, but was produced in bioreactors, formulated and shipped from Germany to Ireland, instead of being produced in the laboratory in wax moth larvae as previously (Dillon et al. 2006, 2007, 2008; Williams et al. 2013a). Production methods may impact on quality of EPN (Grewal and Peters 2005), but there was no evidence that bioreactor-produced $H$. downesi was of lower quality than the insect-produced nematodes used in previous trials (see analysis in supplementary material). Moreover, in the present study we used the EN03 strain of S.carpocapsae, whereas the All strain of the same species was used in previous comparisons (Dillon et al. 2006, 2007, 2008).

Many studies have addressed the effects of soil texture on EPN efficacy, with the emphasis on the mineral component of the soil (e.g. Choo and Kaya 1991; Koppenhöfer and Fuzy 2006), but much of the coniferous forestry in northern temperate regions is planted in peat soils. For example, $45 \%$ of Irish forests have a peat depth of over $30 \mathrm{~cm}$ (Anonymous 2007). Peat soils are characterized by very high organic matter, derived from the accumulation of dead plant material under water-logged, anaerobic conditions. Several recent studies suggest that media with high organic content including peat are favourable for EPN (Kruitbos et al. 2010; Ansari and Butt 2011; Nielsen and Lewis 2011; Wilson et al. 2012). Our results show that both EPN species were as efficacious in peat as in soils classified as mineral. The suitability of this medium for nematodes may be in part due to the high moisture content of peaty soils (Paavilainen and Päivänen 1995; Grant and Villani 2003; Preisser and Strong 2004), movement of nematodes through root ways that might be more accessible in peaty soils (Ennis et al. 2010), and carriage of cues needed for host location at longer distances (Hiltpold and Turlings 2008; Turlings et al. 2012). Our results do not support the previous meta-analysis of studies on using EPN for controlling the LPW, suggesting that efficacy was greater in peat than in mineral soils (Williams et al. 2013b). 'Mineral' is a broad category, encompassing many different sub-types used for forestry, ranging from acid brown earths (well-drained productive soils with good physical properties) to gleys (poorly drained soils with poor soil physical properties (Kennedy 2002). In addition, peat soils also vary based on formation type and subsequent peat extraction practices (Renou and Farrell 2005). For example, deeper layers of cutover blanket bog have poor hydraulic conductivity (hence poor drainage) (Renou and Farrell 2005). Thus, a more refined soil classification would aid in predicting EPN efficacy against LPW. Nonetheless, our study suggests at least that the use of EPN for controlling LPW should not only be determined by soil type, but other factors might also be important (see below).

Our trials also provide some evidence that level of infestation can have important effects on LPW parasitism rates. This can be further confirmed by looking at weevil trap catches; the only site on which EPN did not provide any significant suppression over the control stumps, nor achieved the target number of 20 weevils/stump, was the site with the highest weevil infestation (Clonoghil, adult weevils emerging $\max =468$, median $=102$, Fig. 5) Mechanistically, density dependence can be explained by the reduced capacity of nematodes to reach weevils which are located in deeper roots and horizontally farthest from the bole. In stumps bearing a high numbers of weevils, more of the weevils are located at more distant parts of the roots and thus a higher percentage of weevils escape parasitism by nematodes. Density-dependent parasitism can explain patterns of weevil suppression observed in our trials and also bears important consequences for the use of EPN as biocontrol agents for LPW. For instance, more inoculum might be needed in cases of high infestations (Shapiro-Ilan et al. 2012). However, it should be noted that in our trials the EPN dose applied as determined by other studies (Torr et al. 2005; Dillon et al. 2006, 2007) provided satisfactory control in moderate to high infestation levels, except in one case where infestation levels were extremely high; in this case the efficacy of any other alternative control measure is also questionable.

Passive movement of EPN either by suspension or by later rainfall might be more favoured in peaty soils (Wheeler 1995), but average weevil depth in mineral sites tends to be lower than in deep peat sites. This trend was even more extreme in Clonoghil, a peat site where a relatively small fraction of weevils were found closer to the surface in comparison with other sites of either soil type. In addition, when infestations are high, weevils are found further from the bole, both for mineral and peat sites. More distantly located weevils along the roots are parasitized at lower rates as we demonstrate here and in other studies (Dillon et al. 2006, 2007). These properties of weevil distribution in stumps could explain the relatively equal efficacy of EPN in mineral and peat soils. In other words, EPN movement and survival might be more constrained in mineral sites, but in these sites target weevils are closer to the application point making it easier to be reached by EPN. Moreover, if LPW infestations in peat sites are moderately high, then it is likely that EPN will provide at least an adequate to good level of control. In our study, we also observed that weevils are more abundant in peat sites than in mineral ones. Thus, EPN efficacy in mineral sites can at least be explained by lower weevil infestation rates.

In conclusion, the results of our trials not only confirm previous studies, suggesting that EPN are efficient 
inundative biological control agents of LPW, but also show that two species with different foraging strategies are equally efficient in suppressing LPW populations at the target level sought. In addition, we show that the number of LPW emerging from EPN treated stumps is within targeted threshold levels when densities of weevils in the stumps are moderate, and also that EPN application should not be constrained by soil type which is even more encouraging in widening their use in more cases where LPW control is sought.

\section{Author Contributions}

AK CTG and POT conceived and designed research. AK BM SQ LM CDW conducted experiments. AP provided the entomopathogenic nematodes. AK and CTG analysed data and wrote the manuscript. All authors read and approved the manuscript.

Acknowledgements We thank Abigail Maher for technical support, and numerous forest managers and technicians from Coillte, Ireland, for providing access to sites and helping with trials. This research was funded by the BIOCOMES project co-funded by EU FP7.

\section{Compliance with ethical standards}

Conflict of interest This research was funded by the European Union FP7 under grant agreement $n^{\circ} 612713$ (BIOCOMES project). LM was supported by the Irish Government (Department of Agriculture, Food and the Marine) under the National Development Plan 2007-2013. All authors declare that they have no conflict of interest. This article does not contain any studies with animals performed by any of the authors.

\section{References}

Anonymous (2007) National forest inventory-Republic of Irelandresults. Forest Service, Johnstown Castle

Anonymous (2014) FSC pesticide derogation approval: use of alphacypermethrin in UK. FSC-DER-30-V2-0 EN alpha-cypermethrin UK 150614. Forest Stewardship Council

Ansari MA, Butt TM (2011) Effect of potting media on the efficacy and dispersal of entomopathogenic nematodes for the control of black vine weevil, Otiorhynchus sulcatus (Coleoptera: Curculionidae). Biol Control 58:310-318

Barredo JI, Strona G, de Rigo D, Caudullo G, Stancanelli G, SanMiguel-Ayanz J (2015) Assessing the potential distribution of insect pests: case studies on large pine weevil (Hylobius abietis L.) and horse-chestnut leaf miner (Cameraria ohridella) under present and future climate conditions in European forests. Bull EPPO 45:273-281. doi:10.1111/epp.12208

BIOCOMES Consortium. http://www.biocomes.eu/

Brixey JM, Moore R, Milner AD (2006) Effect of entomopathogenic nematode (Steinernema carpocapsae Weiser) application technique on the efficacy and distribution of infection of the large pine weevil (Hylobius abietis L.) in stumps of Sitka spruce
(Picea sitchensis Carr.) created at different times. For Ecol Manag 226:161-172

Choo HY, Kaya HK (1991) Influence of soil texture and presence of roots on host finding by Heterorhabditis bacteriophora. J Invertebr Pathol 58:279-280

Crawley MJ (1997) GLIM for ecologists. Blackwell Science, Oxford

De Altube MDMM, Strauch O, De Castro GF, Pena AM (2008) Control of the flat-headed root borer Capnodis tenebrionis (Linne) (Coleoptera: Buprestidae) with the entomopathogenic nematode Steinernema carpocapsae (Weiser) (Nematoda: Steinernematidae) in a chitosan formulation in apricot orchards. Biocontrol 53:531-539

Dillon AB, Ward D, Downes MJ, Griffin CT (2006) Suppression of the large pine weevil Hylobius abietis (L.) (Coleoptera: Curculionidae) in pine stumps by entomopathogenic nematodes with different foraging strategies. Biol Control 38:217-226

Dillon AB, Downes MJ, Ward D, Griffin CT (2007) Optimizing application of entomopathogenic nematodes to manage large pine weevil, Hylobius abietis L. (Coleoptera: Curculionidae) populations developing in pine stumps, Pinus sylvestris. Biol Control 40:253-263

Dillon AB, Moore CP, Downes MJ, Griffin CT (2008) Evict or infect? Managing populations of the large pine weevil, Hylobius abietis, using a bottom-up and top-down approach. For Ecol Manag 255:2634-2642

Dillon AB, Foster A, Williams CD, Griffin CT (2012) Environmental safety of entomopathogenic nematodes - effects on abundance, diversity and community structure of non-target beetles in a forest ecosystem. Biol Control 63:107-114

EC (1991) Council Directive 91/414/EEC concerning the placing of plant protection products on the market. Off $\mathrm{J}$ Eur Union 230:1-32

EC (2009a) Council Directive 2009/128/EC establishing a framework for Community action to achieve the sustainable use of pesticides. Off J Eur Union 309:71-86

EC (2009b) Directive Regulation 1107/2009/EC concerning the placing of plant protection products on the market and repealing Council Directives 79/117/EEC and 91/414/EEC. Off J Eur Union 309:1-50

Ehlers R-U, Hokkanen HMT (1996) Insect biocontrol with nonendemic entomopathogenic nematodes (Steinernema and Heterorhabditis spp.): conclusions and recommendations of a combined OECD and COST workshop on scientific and regulatory policy issues. Biocontrol Sci Technol 6:295-302

Ehlers R-U, Shapiro-Ilan DI (2005) Mass production. In: Grewal PS, Ehlers R-U, Shapiro-Ilan D (eds) Nematodes as biocontrol agents. CABI, Wallingford, pp 65-78

Eidmann HH, Lindelow A (1997) Estimates and measurements of pine weevil feeding on conifer seedlings: their relationships and application. Can J For Res 27:1068-1073

Ennis DE, Dillon AB, Griffin CT (2010) Simulated roots and host feeding enhance infection of subterranean insects by the entomopathogenic nematode Steinernema carpocapsae. J Invertebr Pathol 103:140-143

Evans H, Moore R, Heritage S, Wainhouse D (2004) Developments in the integrated management of pine weevil, a pest of restocking in conifer plantations. Forest research annual reports and accounts 2003-2004. Edinburgh, UK

Evans H, McAllister F, Saunders T, Moore R, Jenkins T, Butt T, Ansari M., Griffin C, Williams C, Teck, R, Sweeney J (2015) The Impact project guide to Hyalobius management 2015. http:// www.impactproject.eu/uploads/impact_hylobius_publication.pdf

Gaugler R, Lewis E, Stuart RJ (1997) Ecology in the service of biological control: the case of entomopathogenic nematodes. Oecologia 109:483-489 
Grant JA, Villani MG (2003) Soil moisture effects on entomopathogenic nematodes. J Nematol 15:329-332

Grewal PS, Peters A (2005) Formulation and quality. In: Grewal PS, Ehlers R-U, Shapiro-Ilan D (eds) Nematodes as biocontrol agents. CABI, Wallingford, pp 79-90

Grewal PS, Selvan S, Gaugler R (1994) Thermal adaptation of entomopathogenic nematodes: niche breadth for infection, establishment, and reproduction. J Therm Biol 19:245-253

Grewal PS, Ehlers R-U, Shapiro-Ilan D (2005) Nematodes as biocontrol agents. CABI, Wallingford

Griffin CT (2015) Behaviour and population dynamics of entomopathogenic nematodes following application. In: CamposHerrera R (ed) Nematode pathogenesis of insects and other pests: ecology and applied technologies for sustainable plant and crop protection. Springer International Publishing, Berlin, pp 57-96

Heritage S, Moore R (2001) The assessment of site characteristics as part of a management strategy to reduce damage by Hylobius. Forestry Commission Information Note 38, HMSO, UK

Hiltpold I, Turlings TCJ (2008) Belowground chemical signaling in maize: when simplicity rhymes with efficiency. J Chem Ecol 34:628-635

Inward DJG, Wainhouse D, Peace A (2012) The effect of temperature on the development and life cycle regulation of the pine weevil Hylobius abietis and the potential impacts of climate change. Agric For Entomol 14:348-357

Jansson RK, Lecrone SH, Gaugler R (1993) Field efficacy and persistance of entomopathogenic nematodes (Rhabditida, Steinernematidae, Heterorhabditidae) for control of sweet-potato weevil (Coleoptera, Apionidae) in southern Florida. J Econ Entomol 86:1055-1063

Kennedy F (2002) The identification of soils for forest management. Forestry Commission field guide 19. Forestry Commission, Edinburgh, Scotland

Koppenhöfer AM, Fuzy EMJ (2006) Effect of soil type on infectivity and persistence of the entomopathogenic nematodes Steinernema scarabaei, Steinernema glaseri, Heterorhabditis zealandica, and Heterorhabditis bacteriophora. J Invertebr Pathol 92:11-22

Kruitbos LM, Heritage S, Hapca S, Wilson MJ (2010) The influence of habitat quality on the foraging strategies of the entomopathogenic nematodes Steinernema carpocapsae and Heterorhabditis megidis. Parasitology 137:303-309

Leather SR, Day KR, Salisbury AN (1999) The biology and ecology of the large pine weevil, Hylobius abietis (Coleoptera: Curculionidae): a problem of dispersal? Bull Entomol Res 89:3-16

Meier U (2006) A note on the power of Fisher's least significant difference procedure. Pharm Stat 5:253-263

Moore R (2001) Emergence trap developed to capture adult large pine weevil Hylobius abietis (Coleoptera: Curculionidae) and its parasite Bracon hylobii (Hymenoptera: Braconidae). Bull Entomol Res 91:109-115

Nielsen A, Lewis EE (2011) Designing the ideal habitat for entomopathogen use in nursery production. Pest Manag Sci 68:1053-1061

Örlander GR, Nilsson U (1999) Effect of reforestation methods on pine weevil (Hylobius abietis) damage and seedling survival. Scand J For Res 14:341-354

Örlander GR, Nordlander GR (2003) Effects of field vegetation control on pine weevil (Hylobius abietis) damage to newly planted Norway spruce seedlings. Ann For Sci 60:667-671
Paavilainen E, Päivänen J (1995) Peatland forestry ecology and principles. Ecological studies, vol 111. Springer-Verlag, Berlin

Preisser EL, Strong DR (2004) Climate affects predator control of an herbivore outbreak. Am Nat 163:754-762

Renou F, Farrell EP (2005) Reclaiming peatlands for forestry the Irish experience. In: Stanturf JA, Madsen P (eds) Restoration of boreal and temperate forests. CRC Press, Boca Raton

Shapiro-Ilan D, Han R, Dolinski C (2012) Entomopathogenic nematode production and application technology. J Nematol 44:206-217

Stock P, Griffin CT, Burnell AM (2002) Morphological characterisation of three isolates of Heterorhabditis Poinar, 1997 from the 'Irish group' (Nematoda: Rhabditida: Heterorhabditidae) and additional evidence supporting their recognition as a distinct species, H. downesi sp. Syst Parasitol 51:95-106

Tan JY, Wainhouse D, Day KR, Morgan G (2010) Flight ability and reproductive development in newly emerged pine weevil Hylobius abietis and potential effects of climate change. Agric For Entomol 12:427-434

Thorpe KV, Day KR (2002) The impact of host plant species on the larval development of the large pine weevil Hylobius abietis L. Agric For Entomol 4:187-194

Torr PS, Wilson MJ, Heritage S (2005) Forestry applications. In: Grewal PS, Ehlers R-U, Shapiro-Ilan DI (eds) Nematodes as biocontrol agents. CABI Publishing, Oxfordshire, pp 281-293

Turlings TCJ, Hiltpold I, Rasmann S (2012) The importance of rootproduced volatiles as foraging cues for entomopathogenic nematodes. Plant Soil 358:51-60

von Sydow F, Birgersson G (1997) Conifer stump condition and pine weevil (Hylobius abietis) reproduction. Can J For Res 27:1254-1262

Wainhouse D, Brough S, Greenacre B (2007) Managing the pine weevil on lowland pine. Forestry Commission http://www. forestry.gov.uk/pdf/FCPN014.pdf/FILE/FCPN014.pdf

Wheeler BD (1995) Introduction: restoration and wetlands. In: Wheeler BD, Shaw SC, Fojt WJ, Robertson RA (eds) Restoration of temperate wetlands. John Wiley \& sons, Chichester, pp 1-18

Williams CD, Dillon AB, Harvey CD, Hennessy R, McNamara L, Griffin CT (2013a) Control of a major pest of forestry, Hylobius abietis, with entomopathogenic nematodes and fungi using eradicant and prophylactic strategies. For Ecol Manag 305:212-222

Williams CD, Dillon AB, Girling RD, Griffin CT (2013b) Organic soils promote the efficacy of entomopathogenic nematodes, with different foraging strategies, in the control of a major forest pest: a meta-analysis of field trial data. Biol Control 65:357-364

Williams CD, Dillon AB, Ennis D, Hennessy R, Griffin CT (2015) Differential susceptibility of pine weevil, Hylobius abietis (Coleoptera: Curculionidae), larvae and pupae to entomopathogenic nematodes and death of adults infected as pupae. Biocontrol 60:537-546

Wilson MJ, Ehlers R-U, Glazer I (2012) Entomopathogenic nematode foraging Strategies-is Steinernema carpocapsae really an ambush forager? Nematology 14:389-394

Wilson MJ, Wilson DJ, Rodgers A, Gerard PJ (2016) Developing a strategy for using entomopathogenic nematodes to control the African black beetle (Heteronychus arator) in New Zealand pastures and investigating temperature constraints. Biol Control 93:1-7 